MIDPI

sciforum
MOL2NET, International Conference on Multidisciplinary Sciences, $5^{\text {th }}$ Edition

USINEWS-03: US-IN-EU Worldwide Science Workshop Series, UMN, Duluth,

USA, 2019

\title{
Docking Studies of Epigallocatechin Gallate as Natural DPP-IV Inhibitor
}

\author{
Satish Kumar, Rajeev K Singla *, Arun Garg \\ Drug Design and Discovery Laboratory, School of Medical and Allied Sciences, KR Mangalam \\ University, Sohna Road, Gurugram-122103, India
}

*Address for Correspondence: Rajeev K Singla, rajeevsingla26@gmail.com ; rajeevkumar.singla@krmangalam.edu.in

\begin{tabular}{|l|l|}
\hline Graphical Abstract & $\begin{array}{l}\text { Abstract. } \\
\text { DPP-IV enzyme is one of the important targets } \\
\text { for the anti-diabetic drugs. Natural products like } \\
\text { Epigallocatechin Gallate (EGCG) had been } \\
\text { reported to have antidiabetic action vide } \\
\text { multiple mechanisms which also include } \\
\text { inhibition of DPP-IV enzyme. However, its } \\
\text { mechanism and site of action on DPP-IV enzyme } \\
\text { was not thoroughly explored. Thus, the current } \\
\text { study was aimed to perform docking studies of } \\
\text { EGCG with the DPP-IV enzyme, (PDB ID: } \\
2 P 8 S) \text { using VLife MDS 4.6. Results indicated } \\
\text { that EGCG was successfully docked in the DPP- } \\
\text { IV enzyme with dock score of -87.584 when } \\
\text { compared with standard and co-crystallized } \\
\text { drug (cyclohexalamine inhibitor) which has } \\
\text { dock score of -84.0564. Further interaction } \\
\text { analysis suggested that Epigallocatechin Gallate } \\
\text { has aromatic interactions with Phe357A and } \\
\text { hydrogen bonding with Argl25A, Glu206A and } \\
\text { Arg358A. So based on the current study, } \\
\text { Epigallocatechin Gallate can be further } \\
\text { processed for tailoring and designing of novel } \\
\text { DPP-IVinhibitors. }\end{array}$ \\
\hline$x-1$
\end{tabular}




\section{Introduction}

Diabetes mellitus, a chronic metabolic disorder, which is characterized by the abnormal increase in the blood glucose level in blood plasma. Both genetic and environmental factors are responsible for it, which leads to the either deficiency in the insulin production or resistance of cells to the insulin i.e. insulin resistance [1]. Reports indicated that ageing and diabetic history in the family of male are important demographic risk factors where prediction can be done by assessing the low testosterone levels [2,3]. If unchecked or not properly treated, diabetes mellitus will lead to various macrovascular and microvascular complications and could make patients vulnerable to the infectious diseases [4]. Dipeptidyl-peptidase-IV (DPP-IV), a serine exopeptidase, plays a very critical role in the regulation of glucagon like peptide-1 and glucose-dependent insulinotropic polypeptide. Thus, DPP-IV inhibitors are the target search for the treatment of diabetes mellitus [5,6].

Natural products, be it from plants, marine or microbial sources, have been long used for the treatment of various metabolic disorders like diabetes mellitus [7-10]. Epigallocatechin gallate (EGCG) is a natural polyphenol, available in wide varieties of sources which includes, but not limited to, black tea $[11,12]$, black current [13], cherry [13], forest fruit [13], green tea (Indian) [13], lemon [13], orange [13] and strawberry [13] etc. Literature suggested that EGCG has proven its strong potential for treatment of diabetes by multiple mechanisms which also include inhibition of DPP-IV [14-17].

With the advancement in molecular biology, docking studies and in silico pharmacology studies, enzyme modulators and receptors associated with molecular pathogenesis of the disease are being considered as important targets for treatment of diabetes mellitus [18]. Since the mechanism of epigallocatechin gallate as inhibitor of DPP-IV enzyme was not extensively explored, aim of the current study was to perform docking studies of EGCG with the DPP-IV enzyme and get the insight about the possible site of action.

\section{Materials and Methods}

Structure of EGCG was taken from PubChem and drawn using ChemDraw Ultra software. It was then exported to VLife MDS 4.6 software for energy minimization and docking studies. The structure i.e. PDB file of the DPP-IV enzyme selected was $2 \mathrm{p} 8 \mathrm{~s}$ and taken from the RCSB website. It will also be exported to VLife MDS 4.6 for processing. Parameters selected for the energy minimization of EGCG were: Force Field: Merck Molecular Force Field; Charge: MMFF Charge; Number of cycles: 10,000 with RMS gradient of 0.01 . The parameters fixed for docking simulation was like this: number of placements, 50; rotation angle, $10^{\circ}$; exhaustive method; ligand-wise results: 10; scoring function: dock score $[1,4,19]$.

\section{Results and Discussion}

\begin{tabular}{|l|l|l|l|l|}
\hline $\begin{array}{l}\text { S.N } \\
\text { o. }\end{array}$ & $\begin{array}{l}\text { Name of the } \\
\text { Molecule }\end{array}$ & $\begin{array}{l}\text { Cod } \\
\mathbf{e}\end{array}$ & $\begin{array}{l}\text { Best } \\
\text { Placemen } \\
\mathbf{t}\end{array}$ & $\begin{array}{l}\text { Doc } \\
\mathbf{k} \\
\text { Scor } \\
\mathbf{e}\end{array}$ \\
\hline 1. & $\begin{array}{l}\text { Epigallocatec } \\
\text { hin Gallate }\end{array}$ & 06. & $\begin{array}{l}06 \_ \text {opt_o } \\
\text { pt___P7 } \\
\text { C7_LP7 }\end{array}$ & $\begin{array}{l}- \\
87.6 \\
0\end{array}$ \\
\hline 2. & $\begin{array}{l}\text { Referance } \\
\text { Ligand 417 }\end{array}$ & $-\mathrm{X}-$ & $\begin{array}{r}-\mathrm{X}-\mathrm{X}- \\
\text { X-X-X-X- }\end{array}$ & $\begin{array}{l}- \\
84.1 \\
0\end{array}$ \\
\hline
\end{tabular}

Table 1 Docking score of the EGCG when docked in the co-crystallized tracked active site of DPP-IV enzyme, 2p8s. Dock score is PLP scoring function.

Results indicated that Epigallocatechin Gallate was having strong affinity towards DPP-IV enzyme, with dock score of -87.584 when compared with standard and crystallized drug (cyclohexalamine inhibitor) which has dock score of -84.0564 (Table 1). Further interaction analysis suggested that Epigallocatechin Gallate 
has aromatic interactions with Phe357A and hydrogen bonding with Arg125A, Glu206A and $\operatorname{Arg} 358 \mathrm{~A}$. So based on the current study, Epigallocatechin Gallate can be selected for tailoring and designing novel DPP-IV inhibitors.

\section{References}

1. Singla, R.K.; Dubey, A.K. Phytochemical profiling, GC-MS analysis and $\alpha$-amylase inhibitory potential of ethanolic extract of Cocos nucifera Linn. Endocarp. Endocrine, Metabolic \& Immune Disorders- Drug Targets, 2019, 19, 419-442.

2. Johannes, C.B.; Araujo, A.B.; Feldman, H.A. et al. Incidence of erectile dysfunction in men 40 to 69 years old: longitudinal results from the Massachusetts male aging study. The Journal of Urology, 2000, 163, 460-463.

3. Putta, S.; Peluso, I.; Yarla, N.S.; Kilari, E.K.; Bishayee, A.; Lu, D.Y.; Barreto, G.E.; Ashraf, G.M.; Scotti, L.; Scotti, M.T.; Singla, R.K.; et al. Diabetes mellitus and male aging: Pharmacotherapeutics and clinical implications. Current Pharmaceutical Design, 2017, 23, 44754483.

4. Singla, R.K.; Singh, R.; Dubey, A.K. Important aspects of post-prandial antidiabetic drug, acarbose. Current Topics in Medicinal Chemistry, 2016, 16, 2625-2633.

5. Matteucci, E.; Giampietro, O. Dipeptidyl peptidase-4 (CD26): knowing the function before inhibiting the enzyme. Current Medicinal Chemistry, 2009, 16, 2943-2951.

6. Singla, R.K.; Kumar, R.; Khan, S.; Kumari, K.; Garg, A. Natural Products: Potential Source of DPP-IV Inhibitors. Current Protein \& Peptide Science, 2019.

DOI: 10.2174/1389203720666190502154129

7. Scotti, L.; Singla, R.K.; Scotti, M.T. Natural leads in drug discovery against metabolic disorders and their related infectious diseases. Current Topics in Medicinal Chemistry, 2016, 16, 25232524.

8. Singla, R.K.; Dubey, H.D.; Dubey, A.K. Therapeutic spectrum of bacterial metabolites. Indo Global Journal of Pharmaceutical Sciences, 2014, 4, 52-64.

9. Bhattacharjee, R.; Mitra, A.; Dey, B.; Pal, A. Exploration of anti-diabetic potentials amongst marine species- a mini review. Indo Global
Journal of Pharmaceutical Sciences, 2014, 4, 6573.

10. Dey, B.; Bhattacharjee, R.; Mitra, A.; Singla, R.K.; Pal, A. Mechanistic explorations of antidiabetic potentials of Sansevieria trifasciata. Indo Global Journal of Pharmaceutical Sciences, 2014, 4, 113-122.

11. Bhandari, K.; De, B. In silico molecular GRIP docking studies of antioxidant potentials of black tea compounds. MOL2NET 2017, International Conference on Multidisciplinary Sciences, 3rd edition session USINEWS-01; USIN-EU Worldwide Science Workshop Series, UMN, Duluth, USA, 2017. DOI: 10.3390/mol2net-03-05045

12. Laganà, P.; Anastasi, G.; Marano, F.; Piccione, S.; Singla, R.K.; Dubey, A.K.; Delia, S.; Coniglio, M.A.; Facciolà, A.; Di Pietro, A.; Haddad, M.A. Phenolic Substances in Foods: Health Effects as AntiInflammatory and Antimicrobial Agents. Journal of AOAC International, 2019, 102. DOI: 10.5740/jaoacint.19-0131

13. Gadkari, P.V.; Balaraman, M. Catechins: sources, extraction and encapsulation: a review. Food and Bioproducts Processing, 2015, 93, 122-138.

14. Xiaopeng, L.; Shuyi, L.; Mo, C.; Jingyi, W.; Bijun, X.; Zhida, S. (-)-Epigallocatechin-3-gallate (EGCG) inhibits starch digestion and improves glucose homeostasis through direct or indirect activation of PXR/CAR-mediated phase II metabolism in diabetic mice. Food \& Function, 2018, 9, 4651-4663.

15. Tang, L.; Li, L.; Yang, J.; Zeng, C. Potential benefit of (-)-epigallocatechin-3-gallate for macrovascular complications in diabetes. Brazilian Journal of Medical and Biological Research, 2017, 50, e6511. DOI: 10.1590/1414$431 \times 20176511$

16. Wolfram, S.; Raederstorff, D.; Preller, M.; Wang, Y.; Teixeira, S.R.; Riegger, C.; Weber, P. Epigallocatechin gallate supplementation alleviates diabetes in rodents. The Journal of Nutrition, 2006, 136, 2512-2518.

17. Song, W-Y.; Aihara, Y.; Hashimoto, T.; Kanazawa, K.; Mizuno, M. (-)- Epigallocatechin-3-gallate induces secretion of anorexigenic gut hormones. Journal of Clinical Biochemistry and Nutrition, 2015, 57, 164-169. 
18. De, B.; Bhandari, K.; Chakravorty, N.; Mukherjee, R.; Gundamaraju, R.; Singla, R.K.; Katakam, P.; Adiki, S.K.; Ghosh, B.; Mitra, A. Computational pharmacokinetics and in vitro-in vivo correlation of anti-diabetic synergistic phyto-composite blend. World Journal of Diabetes, 2015, 6, 1179.

19. Singla, R.K.; Ali, M.; Kamal, M.A.; Dubey, A.K. Isolation and characterization of nuciferoic acid, a novel keto fatty acid with hyaluronidase inhibitory activity from Cocos nucifera Linn. endocarp. Current Topics in Medicinal Chemistry, 2018, 18, 2367-2378. 